УДК 930.2:[001.89-057.875:378.4(477.83-25)ЛПІ]"196/197"

DOI: https://doi.org/10.31652/2411-2143-2021-38-56-61

\title{
Ростислав Мельник
}

Національний університет «Львівська політехніка», кандидат історичних наук, старший викладач (Україна) e-mail: rimarch2010@yahoo.com

ORCID: https://orcid.org/0000-0003-0375-7167

\section{Студентське проектно-конструкторське бюро Львівського політехнічного інституту у 1960-х - 70-х рр.: напрями та форми діяльності}

Анотація. Мета статmі полягає у висвітленні основних напрямів та форм науководослідної діяльності Студентського проектно-конструкторського бюро Львівського політехнічного інституту у 1960-х - 70-х рр. Зокрема, автор розглядає і характеризує види науково-дослідних робіт, які виконувалися працівниками бюро, способи й методи виконання цих робіт студентами. Методологічною основою дослідження $\epsilon$ загальнонаукові (аналізу, синтезу, узагальнення) та спеціально-історичні (історико-генетичний, історикопорівняльний, історико-типологічний) методи, а також принципи історизму, об'єктивності та верифрікації. Наукова новизна роботи полягає у тому, що на підставі архівних джерел та публікацій радянської періодики проаналізовано особливості та характер діяльності Студентського проектно-конструкторського бюро Львівського політехнічного інституту в 1960-х - 70-х рр., розелянуто основні напрями й фоорми науково-дослідної діяльності бюро, його співпраці з народним господарством. Висновки. Створення та діяльність Студентського проектно-конструкторського бюро у 1960-х - 70-х рр. було важливим етапом у розвитку Львівського політехнічного інституту як навчального й наукового центру. Це впорядкувало науково-дослідну діяльність студентів, підвищило рівень і якість виконання ними науково-дослідних робіт, надало цим роботам більщої ваги та значення. У рамках бюро розвинулися старі й з'явилися нові напрями й фоорми науково-дослідної діяльності студентів, розширилося коло науково-дослідних робіт та дослідницьких завдань, котрі стояли перед молодими політехніками, урізноманітнилася їх тематика. Це сприяло зростанню статусу й авторитету бюро, підвищило його роль у системі науково-дослідних підрозділів інституту, утвердило його позиції як самодостатнього науково-дослідного осередку.

Ключові слова: Львівський політехнічний інститут, народне господарство, науководослідна діяльність, студенти, Студентське проектно-конструкторське бюро.

Постановка проблеми. Діяльність Львівської політехніки (у радянські часи - Львівський політехнічний інститут, далі - ЛПІ) завжди відзначалася високою науковою активністю студентства й широким залученням його представників до виконання науково-дослідних робіт, які провадив заклад. У радянський період з його всеосяжною інтеграцією вищої технічної школи з народним господарством, а відтак ії підпорядкування інтересам соціалістичної економіки, участь студентів у науково-дослідній діяльності набувала не лише практичного, а й, без сумніву, ідеологічного значення. А тому пошуку оптимальної моделі організації науково-дослідної роботи студентів керівництво інституту відводило чимало уваги, часу, зусиль і ресурсів. I слід визнати, що робило це досить успішно. Студенти дійсно стали важливою складовою і чинником наукового життя закладу. Їхня діяльність характеризувалася хорошими результатами, більшість з яких використовувалася в інтересах самого інституту або ж ефективно впроваджувалася у промисловість і виробництво. I хоча активну наукову діяльність студенти ЛПІ розпочали одразу після відновлення роботи закладу у 1944 р., справжніх організаційних форм вона набула дещо пізніше - у 1950-х рр. Важливу роль у цьому відіграло створення у 1959 р. Студентського проектно-конструкторського бюро (далі - СПКБ). Воно було покликане впорядкувати науководослідну діяльність студентів, узгодити її з поточними потребами й проблемами стратегічного розвитку вузу, допомагати промисловості й виробництву у вирішенні наукових і технічних завдань різного рівня. Водночас СПКБ виконувало для студентів роль своєрідного майданчика, де вони могли застосувати на практиці здобуті під час навчання знання і навики, вдосконалити і поглибити їх, ознайомитися з основами науково-дослідної роботи та професійної діяльності за обраним фрахом.

Аналіз джерел та останніх досліджень. Загальний інтерес до СПКБ виник одразу ж після його створення. Значні успіхи бюро у проєктно-конструкторській і науково-дослідній діяльності, яких йому вдалося досягти у 1960-х - 70-х рр., ще більше привернули до нього увагу науковців і громадськості. Результатом цього стала серія різних публікацій, присвячених СПКБ, 
які впродовж 1960-х - 80-хрр. регулярно виходили в газеті ЛПІ «Радянський студент». Не претендуючи на роль ґрунтовних наукових розвідок, часто переслідуючи ідеологічні цілі, вони, однак, містили багато цінної інформації про структуру й організацію діяльності СПКБ, його співпрацю з промисловістю та виробництвом, її результати, впровадження цих результатів на практиці тощо. У своїй сукупності вони становлять важливе, а часто - незамінне джерело з історії бюро у 1960-х - 80-х pp. Не перелічуючи тут усіх публікацій, слід зазначити основні з них. Це, зокрема, статті, авторами яких були В. Осепчугов (Осепчугов, 1959), В. Ларіна (Ларіна, 1971), П. Путій (Путій, 1973), А. Берестовська (Берестовська, 1977), О. Телеп (Телеп, 1977; Телеп, 1979), І. Огородник (Огородник, 1979), В. Лясковська (Лясковська, 1984). Інформацію про діяльність СПКБ у 1960-х -70-х рр. можна знайти також на сторінках таких всесоюзних і республіканських наукових періодичних видань: «Вестник высшей школы» (Харченко, 1960; Богацкий, 1972), «Строительство и архитектура» (Проектируют студенты, 1979), «Архитектура СССР» (Студенческое проектно-конструкторское бюро, 1985), «Знання та праця» (Складаний, 1978). Діяльності СПКБ присвячено також фрагмент монографії Р. Кузьмина та Р. Мельника про діяльність Науково-дослідного сектору ЛПІ у 1944-1978 рр., яка побачила світ у 2020 р. (Кузьмин, 2020).

Мета статті - висвітлити основні напрями та форми діяльності СПКБ ЛПІ у 1960-х 70-х рр., розглянути й охарактеризувати види робіт, які виконувалися у бюро у той період часу, способи й методи виконання студентами цих робіт.

Виклад основного матеріалу. Свою роботу СПКБ проводило у декількох напрямах, які тісно переплітаючись та доповнюючи один одного, творили багату картину діяльності цього підрозділу. В основі цієї діяльності була розробка різноманітних архітектурно-будівельних й інфрраструктурних проєктів. Власне для реалізації перспективного плану розбудови об’єктів і розвитку матеріально-технічної бази ЛПІ бюро й було створене. СПКБ повністю виправдало покладені на нього сподівання. Упродовж 1960-х - 70-х рр. його працівниками - штатними співробітниками, викладачами й студентами - розроблено проєктну документацію для великої кількості об'єктів інституту різного призначення - навчального, господарського, житлового, рекреаційного. Слід зазначити, що діяльність бюро не обмежувалося лише розробкою архітектурно-будівельних проєктів для інституту. Воно надавало ВНЗ також різносторонню наукову, технічну й організаційну допомогу. Так, у 1977 р. для розвитку й вдосконалення навчально-матеріальної бази інституту студентами (під керівництвом професорськовикладацького складу) виготовлено у СПКБ 190 лабораторних установок, 50 навчальних пристроїв, більш ніж 2 тис. плакатів і схем, близько 5 тис. штук карт програмування і контролю та інших посібників [ДАЛО. Ф. Р-120. Оп. 6. Спр.717. Арк.207].

На засадах госпрозрахунку СПКБ займалося розробкою проєктно-будівельної документації для промислових і виробничих підприємств, установ й організацій [ДАЛО. Ф. Р-120. Оп.6. Спр.135. Арк.149-151]. Виконуючи ці та інші роботи, воно співпрацювало 3 підприємствами й організаціями не лише Львова чи області, а й всієї УРСР [ДАЛО. Ф. Р-120. Оп.6. Спр.171. Арк.106]. Результати діяльності СПКБ у галузі архітектурнобудівельного проєктування ще у середині 1960-хрр. отримали високу оцінку та широко застосовувалися на практиці архітекторами й інженерами-будівельниками зі всього Радянського Союзу [ДАЛО. Ф.Р-120. Оп.6. Спр.171. Арк.107]. Не менш активно бюро працювало і в 1970-х рр. У той час його працівниками й студентами виконано чимало проєктів на замовлення різних установ, підприємств та відомств [ДАЛО. Ф. Р-120. Оп.6. Спр.293. Арк.319-322]. Але навіть за таких обставин у бюро переважали роботи, які виконувалися на замовлення ЛПІ. Так, у 1972 р. розробка проєктно-конструкторської документації для інженерно-будівельних потреб інституту становила аж $65 \%$ усіх його робіт. На виконання замовлень інших закладів вищої освіти припадало лише $10 \%$ робіт, міністерств та відомств - $25 \%$ [ДАЛО. Ф. Р-120. Оп.6. Спр.360. Арк.220]. Окремим дозволом Держцивільбуду СРСР у 1974 р. СПКБ отримало ексклюзивне право на розробку індивідуальних проєктів об'єктів житлового й цивільного будівництва [Лясковська, 1984]. Того ж року архітектурно-будівельна група у складі бюро проєктувала низку об'єктів за завданням Міністерства вищої освіти УРСР [ДАЛО. Ф. Р-120. Оп.6. Спр.501. Арк.168].

Окремий напрям діяльності СПКБ становили проєктно-конструкторські, науково-пошукові й дослідницькі роботи, а також різноманітні лабораторні й експериментальні дослідження. Зазвичай їх виконували на госпрозрахункових засадах. Замовниками цих робіт переважно виступали підприємства й організації народного господарства - заводи, фабрики, виробничі об'єднання тощо. Вони представляли не лише Львів та Львівську область, а й інші регіони України [ДАЛО. Ф. Р-120. Оп.6. Спр.135. Арк.147]. Більшість їхніх замовлень стосувалася разових, нетривалих за часом виконання робіт. Динаміка їх зростання вражала. Так, якщо у першій половині 1960-х рр. обсяг виконаних у бюро замовлень не перевищував 80 на рік [ДАЛО. Ф. Р-120. Оп.6. Спр.135. Арк.152], то вже у другій половині 1960-х рр. їх кількість щороку 
становила у середньому 200 [ДАЛО. Ф. Р-120. Оп.6. Спр.171. Арк.109]. На такому ж високому рівні цей показник залишався і в 1970-х рр. [ДАЛО. Ф. Р-120. Оп.6. Спр.293. Арк.324-325].

Спектр робіт, які СПКБ виконувало для промисловості й виробництва, був надзвичайно широким та охоплював різні галузі науки й техніки, а також сфрери життєдіяльності суспільства. Для прикладу можна навести діяльність бюро у 1971 р. Тоді у його навчально-виробничих лабораторіях виконувалися такі роботи: фізико-хімічне дослідження ґрунтів (лабораторії кафедри автодоріг); фрізико-механічні й хімічні аналізи будматеріалів (лабораторії кафедри технології силікатів); механічні дослідження зразків металів, тросів, деревини та ін. (лабораторії кафредри опору матеріалів); металографрічні дослідження сталей, чавунів та ін. металів (лабораторії кафедри фрізики металів і металознавства); хімічні аналізи різних металів, кислот, вод та ін. речовин (лабораторії кафедри аналітичної хімії); аналізи трансформаторних і турбінних мастил (лабораторії кафедри технології нафтти і газу); високовольтні дослідження заземлень та різних захисних засобів (лабораторії кафедри електричних станцій); комплексні перевірочні рентгенівські дослідження зварювальних робіт різних конструкцій, споруд та об'єктів (лабораторії кафедри зварювального виробництва); перевірка й реконструкція елементів теплоенергетичних установок (лабораторії кафедри теплоенергетичних установок електричних станцій); розрахунки й експертні перевірочні розрахунки з роботи різних підйомно-транспортних машин й агрегатів (лабораторії кафедр ПТМ і ТММ); виконання різних технічних і технологічних експертиз (лабораторії кафедр технічного й технологічного профілю); переклади 3 західноєвропейських мов на російську і з російської мови на західноєвропейські технічної літератури - статей, описів, рекламацій, рефератів та ін. тестів (студенти кафредри іноземних мов) [ДАЛО. Ф. Р-120. Оп.6. Спр.293. Арк.324-325].

СПКБ також проводило для установ, підприємств й організацій народного господарства Львова та західних областей України значні за обсягом та тривалі за часом виконання науковопошукові, проєктно-конструкторські і дослідницькі роботи. Це відбувалося на підставі відповідних договорів. Зокрема, у 1969 р. співробітники СПКБ та студенти працювали над реалізацією 6-ти договорів 3 промисловістю i виробництвом [ДАЛО. Ф. Р-120. Оп.6. Спр.205. Арк.297]. У 1979 р. таких договорів було 15. Більшість із них довготривалі (на 2-3 роки), а кошторис прописаних у них робіт у середньому становив 20000 крб [Огородник, 1979].

Розширення активності СПКБ, зростання його ваги у житті ЛПІ, підвищення авторитету серед наукових і промислових кіл спричинили появу у середині 1970-х рр. нової форми діяльності цього підрозділу - договорів про творчу співдружність з науковими інституціями, промисловістю і виробництвом. Наприкінці 1970-х рр. СПКБ мало укладені договори про творчу співдружність з цілою низкою установ, підприємств й організацій зі всієї УРСР. Серед них, зокрема, були: Фізико-механічний інститут АН УРСР, обчислювальний центр Харківського інституту інженерів комунального будівництва, науково-дослідні та проєктні лабораторії експериментального проєктування житлових та громадських споруд при Одеському інженернобудівельному інституті [Яківчик, 1978].

Основною метою діяльності СПКБ було забезпечення широкого кола практичних й стратегічних потреб ЛПІ, а також надання допомоги установам, підприємствам та організаціям, які зверталися до нього для вирішення різних технічних й виробничих проблем. Не дивно, що ця діяльність, так само як і її результати, мала здебільшого прикладний характер. Проєктні й конструкторські роботи істотно переважали над науково-дослідними. Наглядним прикладом для підтвердження цих слів може бути 1973 р. Тоді загальний обсяг робіт, виконаних у СПКБ, у відсотковому співвідношенні розподілявся так: проєктні - $45 \%$, приладобудівні (конструкторські) - 45 \%, дослідницькі (науково-дослідні) - 10 \% [ДАЛО. Ф. Р-120. Оп.6. Спр.426. Арк.221].

Спершу студенти працювали у СПКБ лише у вільний від занять час. Згодом із розширенням його діяльності, спричиненої збільшенням кількості замовлень, які надходили до бюро від промисловості й виробництва, та підвищенням рівня їх складності, більшість пошукових, проєктних та науково-дослідних робіт у ньому почали виконуватися у рамках дипломного й курсового проєктування студентів, а також у процесі проходження ними навчально-виробничої та переддипломної практики. Навчально-виробничу практику студенти почали проходити у СПКБ ще у 1960-х рр. Щоправда, у той час щороку ї̈ відбувало заледве 100 осіб [ДАЛО. Ф. Р-120. Оп.6. Спр.171. Арк.106; Спр.187. Арк.283; Спр.205. Арк.292]. У 1970-х рр. та з кожним наступним роком практику у СПКБ проходило все більше і більше студентів. Уже в 1976 р. їх кількість сягнула 500 [ДАЛО.Р-120. Оп.6. Спр.659. Арк.219]. Загалом за перших 20 років існування СПКБ навчально-виробничу й переддипломну практику у ньому пройшли 12583 студенти [Телеп, 1979].

Проєктні, конструкторські й науково-дослідні роботи, які виконувалися у СПКБ, часто ставали темами дипломних і курсових робіт молодих політехніків. Зокрема, у 1972 р. тут 
виконували 58 дипломних і 56 курсових студентських проєктів [ДАЛО. Ф. Р-120. Оп.6. Спр.360. Арк.220]. Незабаром кількість проєктів, реалізованих студентами у бюро, зросла у рази. Так, у 1977 р. ними виконано у СПКБ 164 дипломні роботи. Кількість курсових робіт становила 284 [ДАЛО. Ф. Р-120. Оп.6. Спр.717. Арк.206]. Загалом до 1979 р. у бюро реалізовано понад 1800 курсових і 1200 дипломних студентських проєктів. Більшість із них виконано на замовлення промислових підприємств й організацій. Результати багатьох проєктів керівництво інституту передавало промисловості й виробництву для впровадження, чимало з них знайшли застосування у різних галузях науки і техніки [Телеп, 1979].

Окрім виконання проєктно-конструкторських та науково-дослідних робіт, штатні співробітники СПКБ та студенти, які брали участь у його роботі, використовували у 1960-х 70-хрр. також інші форми науково-дослідної діяльності. До них, зокрема, належали: виголошення студентами на науково-технічних конференціях доповідей, підготовлених на підставі науково-дослідних робіт, які виконувалися у бюро; підготовка й публікація студентами наукових статей і розвідок; підготовка й подання співробітниками бюро заявок на авторські свідоцтва; організація та проведення в інституті конференцій та наукових семінарів [ДАЛО. Ф. Р-120. Оп.6. Спр.659. Арк.219].

Висновки. Створення Студентського проектно-конструкторського бюро було не просто важливим чи необхідним кроком, а цілком закономірним етапом інституційного розвитку Львівського політехнічного інституту як навчального й наукового центру. Окрім того, що його поява створила умови для залучення більшої кількості студентів до науково-дослідної роботи, вона впорядкувала їх діяльність у цьому напрямі, підвищила рівень і якість виконання студентами науково-дослідних робіт, надала цим роботам та їх результатам більшої ваги і значення. СПКБ дало поштовх для розвитку старих й освоєння студентами нових напрямів і форм науково-дослідної діяльності, охоплення цією діяльністю нових видів науково-дослідних робіт, виконання яких силами більших колективів було можливим лише у фрорматі бюро. Розширилася врешті і сама тематика цих робіт. Все це сприяло зростанню статусу й авторитету СПКБ як серед науковців, так і представників народного господарства, його ролі й значення у системі науково-дослідних підрозділів ЛПІ, а відтак утвердженню позицій бюро як самобутнього і самодостатнього науково-дослідного осередку.

Подяка. Висловлюю щиру вдячність усім членам редколегії журналу за консультації, надані під час підготовки статті до друку.

Фінансування. Автор не отримав фрінансової підтримки для дослідження, авторства та публікації цієї статті.

\section{Джерела та література:}

Берестовська, А. (1977). СПКБ творить, дерзає. Радянський студент, 16 березня, № 9 (1409). Богацкий, Г. (1972). Вырабатывать навыки исследователя. Вестник высшей школы, 3. ДАЛО - Державний архів Львівської області.

Кузьмин, Р., Мельник, Р. (2020). Науково-дослідний сектор Львівського політехнічного інституту в 1944-1978 рр. Львів: Видавництво Львівської політехніки, 364 с.

Ларіна, В. (1971). Сьогодні і завтра СПКБ. Радянський студент, 13 січня. № 2 (1164).

Лясковська, В. (1984). 25 років творення... Радянський студент, 19 грудня. № 38 (1711).

Огородник, І. (1979). База науково-практичної підготовки студентів. Радянський студент, 31 січня. №4 (1483).

Осепчугов, В. (1959). Студентське проектно-конструкторське бюро. Радянський студент, 7 квітня. № 12 (529).

Проектируют студенты (1979). Строительство и архитектура, 4, С. 27.

Путій, П. (1973). Творчий шлях до знань. Радянський студент, 31 жовтня. № 31 (1221).

Складаний, І. (1978). Пошуку золота пора. Знання та праця, 9, С. 1-5.

Студенческое проектно-конструкторское бюро Львовской политехники (1985).

Архитектура СССР, 4, С. 38-39.

Телеп, О. (1977). 3 творчим натхненням. Радянський студент, 1 червня. № 19 (1419).

Телеп, О. (1979). СПКБ минуло 20... Радянський студент, 30 грудня. № 39 (1518).

Харченко, В. (1960). Студенческое проектно-конструкторское бюро. Вестник высшей школы, 1. C. 58-59.

Яківчик, Р. (1978). Досягнення й проблеми СПКБ. Радянський студент, 8 лютого. № 5 (1445). 


\section{Ростислав Мельник}

Национальный университет «Львовская политехника», кандидат исторических наук, старший преподаватель (Украина)

\section{Студенческое проектно-конструкторское бюро Львовского политехнического института в 1960-х - 70-х годах: направления и формы деятельности}

Аннотация. Целью статьи является освещение основных направлений и фрорм научно-исследовательской деятельности Студенческого проектно-конструкторского бюро Львовского политехнического института в 1960-х-70-х ге. В частности, автор рассматривает и характеризирует виды научно-исследовательских работ, которые выполнялись работниками бюро, способы и методы выполнения студентами этих работ. Методологической основой исследования стали общенаучные (анализа, синтеза, обобщения) и специально-исторические (историко-генетический, историко-сравнительный, историко-типологический) методы, а также принципы историзма, объективности и верификации. Научная новизна состоит в том, что на основании архивных источников и публикаций советской периодики проанализированы особенности и характер деятельности Студенческого проектно-конструкторского бюро Львовского политехнического института в 1960-х - 70-х г2., рассмотрены основные направления и фрормы научно-исследовательской деятельности бюро, его сотрудничества с народным хозяйством. Выводы. Создание и деятельность Студенческого проектно-конструкторского бюро в 1960-х - 70-х г2. было важным этапом в развитии Львовского политехнического института как учебного и научного центра. Это упорядочило научно-исследовательскую деятельность студентов, повысило уровень и качество выполнения ими научно-исследовательских работ, придало этим работам больше веса и значения. В рамках бюро развились старые и появились новые направления и формы научно-исследовательской деятельности студентов, расширился круг научно-исследовательских работ и задач, стоявших перед молодыми политехниками, разнообразилась их тематика. Это способствовало росту статуса и авторитета бюро, повысило его роль в системе научно-исследовательских подразделений института, утвердило его позиции в качестве самодостаточного научно-исследовательского центра.

Ключевые слова: Львовский политехнический институт, народное хозяйство, научноисследовательская деятельность, студенты, студенческое проектно-конструкторское бюро.

\section{Rostyslav I. Melnyk}

Lviv Polytechnic National University, PhD (History), Senior Lecturer (Ukraine)

\section{Student Design and Engineering Bureau of Lviv Polytechnic Institute in the 1960s - 70s: Directions and Forms of Activities}

Abstract. The purpose of the article is to highlight the main directions and forms of research activities of the Student Design and Engineering Bureau of Lviv Polytechnic Institute in the 1960s 70s. In particular the author considers and characterizes the types of research performed by employees of the bureau, as well as the ways and methods of performing these works by students. The methodological basis of the study are general scientific (analysis, synthesis, generalization) and special-historical (historical-genetic, historical-comparative, historical-typological) methods, as well as the principles of historicism, objectivity and verification. The scientific novelty of the work is that on the basis of archival sources and publications of Soviet periodicals the features and nature of the activity of the Student Design and Engineering Bureau of Lviv Polytechnic Institute in the 1960s - 70s were analyzed. The main directions and forms of research activities of the bureau as well as its cooperation with the national economy are also considered. Conclusions. The establishment and operation of the Student Design and Engineering Bureau of Lviv Polytechnic Institute in the 1960s 70 s was an important stage in the development of Lviv Polytechnic Institute as an educational and research center. This regulated the research activities of students, improved the level and quality of their research works, gave more weight and importance to this work. In the bureau the old directions and forms of research activities of students were developed and new ones appeared. The range of research works and tasks facing young polytechnics expanded. Their topics become more diverse. This contributed to the growth of the status and authority of the bureau, increased its role in the system of research units of the institute, confirmed its position as a self-sufficient research center.

Key words: Lviv Polytechnic Institute, national economy, research activities, students, Student Design and Engineering Bureau. 


\section{References:}

Berestovsjka, A. (1977). SPKB tvorytj, derzaje [SDEB creates, goes ahead]. Radjansjkyj student Soviet student, 16 bereznja, 9 (1409). [in Ukrainian].

Bogatskiy, G. (1972). Vyrabatyvat navyki issledovatelya [To develop researcher skills]. Vestnik vysshey shkoly - Higher School Bulletin, 3. [in Russian].

DALO - Derzhavnyi arkhiv Ljvivsjkoji oblasti. [State archives of Lviv Oblast]. [in Ukrainian].

Jakivchyk, R. (1978). Dosjaghnennja i problemy SPKB [Achievements and challenges of SDEB]. Radjansjkyj student - Soviet student, 8 ljutogho, 5 (1445). [in Ukrainian].

Kharchenko, V. (1960). Studencheskoe proektno-konstruktorskoe byuro [Student Design and Engineering Bureau]. Vestnik vysshey shkoly - Higher School Bulletin, 1, 58-59. [in Russian]

Kuzjmyn, R., Meljnyk, R. (2020). Naukovo-doslidnyj sektor Ljvivsjkogho politekhnichnogho instytutu v 1944-1978 rr. [Research sector of Lviv Polytechnic Institute in 1944-1978]. Ljviv: Vydavnyctvo Ljvivsjkoji politekhniky, 364 p. [in Ukrainian].

Larina, W. (1971). Sjoghodni i zavtra SPKB [SDEB today and tomorrow]. Radjansjkyj student - Soviet student, 13 sichnja, 2 (1164). [in Ukrainian].

Ljaskovsjka, V. (1984). 25 rokiv tvorennja... [25 years of creations]. Radjansjkyj student - Soviet student, 19 ghrudnja, 38 (1711). [in Ukrainian].

Oghorodnyk, I. (1979). Baza naukovo-praktychnoji pidghotovky studentiv [Base of scientific and practical training of students]. Radjansjkyj student - Soviet student, 31 sichnja, 4 (1483). [in Ukrainian].

Osepchughov, V. (1959). Studentsjke proektno-konstruktorsjke bjuro [Student Design and Engineering Bureau]. Radjansjkyj student - Soviet student, 7 kvitnja, 12 (529). [in Ukrainian].

Proektiruyut studenty [Student design] (1979). Stroitelstvo $i$ arkhitektura - Construction and architecture, 4, 27. [in Russian].

Putii, P. (1973). Tvorchyj shljakh do znanj [Creative path to knowledge]. Radjansjkyj student - Soviet student, 31 zhovtnja, 31 (1221). [in Ukrainian].

Skladanyj, I. (1978). Poshuku zolota pora [Golden time of search]. Znannja i pracja - Knowledge and work, 9, 1-5. [in Ukrainian].

Studencheskoe proektno-konstruktorskoe byuro Lvovskoy politekhniki [Student Design and Engineering Bureau of Lviv Polytechnic] (1985). Architektura SSSR - Architecture of the USSR, 4, 3839. [in Russian].

Telep, O. (1977). Z tvorchym natkhnennjam [With creative inspiration]. Radjansjkyj student - Soviet student, 1 chervnja, 31 (1221). [in Ukrainian].

Telep, O. (1979). SPKB mynulo 20 rokiv... [SDEB turned 20]. Radjansjkyj student - Soviet student, 30 ghrudnja, 39 (1518). [in Ukrainian]. 